\title{
0 rozgraniczaniu statutów i wsysaniu regulacji prawnej (na przykładzie prawa stosowanego do oceny różnych aspektów powołania i funkcjonowania wykonawcy testamentu i zarządcy sukcesyjnego przedsięhiorstwem]
}

\begin{abstract}
The position of the executor of the will is governed by the law applicable to succession (Article 23(2)(f) of the EU Regulation 650/2012), while the position of the succession administrator of the estate of a business of a physical person located in Poland is subject to the Law of 5 July 2018 on the succession administration of the business of a physical person (the legal basis for such solution is in Article 30 of the EU Regulation 650/2012). However, if the court needs to determine the law applicable to certain aspects of appointing or functioning of these institutions, which have a nature of partial or preliminary questions, these laws will apply, as determined in line with the methods elaborated to deal with partial and preliminary questions in private international law.

The rules devoted to the executors of wills are usually not self-standing. In such situations, the legislators most often call for supportive application of the rules designed for other matters existing in the same legal system (here - of the legis successionis). This is referred to as the absorption of the legal rules.
\end{abstract}

Keywords: executor of the will, succession administrator of the estate, lex successionis, the law applicable to the administration of the estate, absorbing rules into legis successionis, partial issue, preliminary issue

a) Prof. zw. dr hab., Akademia Leona Koźmińskiego. 


\section{Uwagi wstępne}

Ustawa z dnia 5 lipca 2018 r. o zarządzie sukcesyjnym przedsiębiorstwem osoby fizycznej ${ }^{1}$ [dalej: ustawa z 2018 r.] wprowadziła do naszego prawa, obok dotychczas istniejących, nowy instrument zarządu przedsiębiorstwem jako składnikiem spadku. Jego celem jest ochrona przedsiębiorstwa przed upadkiem $\mathrm{w}$ razie śmierci przedsiębiorcy. Nie uległy przy tym zmianie przepisy kodeksu cywilnego określajace prawnospadkowe tytuły nabycia przedsiębiorstwa (dziedziczenie ustawowe i testamentowe, zapis windykacyjny). W dalszym ciagu dopuszczalne jest powołanie przez spadkodawcę wykonawcy (wykonawców) testamentu (art. 986 § 1 k.c.).

Spadkodawca może powołać wykonawcę testamentu nie tylko do sprawowania zarządu całym spadkiem, lecz również jego zorganizowaną częścią (np. przedsiębiorstwem) lub oznaczonym składnikiem (art. $986^{1}$ k.c.). Może też powołać wykonawcę testamentu do zarządu przedmiotem zapisu windykacyjnego (art. $990^{1}$ k.c.), którym może być m.in. przedsiębiorstwo (art. $981^{1} \S 2$ pkt 3 k.c.) ${ }^{2}$.

Ustawa z 2018 r. stworzyła możliwość powołania przez spadkodawcę, a po jego śmierci przez inne osoby, zarządcy sukcesyjnego sprawującego w określonym (ograniczonym) czasie zarząd przedsiębiorstwem zmarłego przedsiębiorcy. W myśl art. 21 ust. 1 tej ustawy zarządca występując $\mathrm{w}$ tej roli działa wprawdzie w imieniu własnym, lecz w cudzym interesie (na rachunek „właściciela przedsiębiorstwa w spadku”) ${ }^{3}$.

${ }^{1}$ Dz.U. 2018, poz. 1629.

${ }^{2} \mathrm{Na}$ temat wykonawcy testamentu jako zarządcy przedsiębiorstwem zob. m.in.: K.A. Dadań ska: Sukcesja przedsiębiorstw — „de lege lata” $i$ „de lege ferenda”. W: Prawo rodzinne $i$ spadkowe wobec wspótczesnych zjawisk technologicznych $i$ społecznych. Red. J.M. Łukasiewicz, M. Załucki. Toruń 2018, s. 372 i n.; J. Górecki: Zapis windykacyjny w praktyce notarialnej. „Rejent” 2012, nr 4, s. 20 i n.; P. K siężak: Zapis windykacyjny. Warszawa 2012, s. 115 i n.; J. Waszczuk-Napiórkowska: Zapis windykacyjny $w$ polskim prawie spadkowym. Warszawa 2014, s. 207 i n.; J. Blajer: Nabycie przedsiębiorstwa będacego przedmiotem zapisu windykacyjnego. Warszawa 2016, s. 226 i n.; K. Osajda: Kodeks cywilny. Komentarz. Spadki. T. 4A. Warszawa 2019, s. 684, Nb 41 i 42, s. 733 i n., Nb 246 i n.; M. Pazdan: Zarzadca sukcesyjny a wykonawca testamentu. W: „Ius est ars boni et aequi”. Księga pamiatkowa dedykowana Profesorowi Józefowi Frackowiakowi. Red. A. Dańko-Roesler, M. Leśniak, M. Skory, B. Sołtys. Wrocław 2018, s. 885 i n.; J. Głow acz: Wykonawca testamentu w prawie polskim na tle porównawczym. Poznań 2018, s. 148 i n.; P. Pacek: Wykonawca testamentu a zarzqd sukcesyjny przedsiębiorstwem osoby fizycznej - wybrane zagadnienia. „Rejent” 2019, nr 6, s. 61 i n.; R. Kapkowski, M. Kaufmann: Charakter prawny zarzadcy sukcesyjnego na tle pokrewnych instytucji zarzadu masq spadkowa. „Rejent” 2019, nr 7, s. 61 i n.

${ }^{3}$ Ocena charakteru prawnego zarządcy sukcesyjnego jest w literaturze sporna. Najszerzej reprezentowane jest stanowisko, że zarząd sukcesyjny należy objąć pojęciem sze- 
Poszukując rozstrzygnięć kolizyjnoprawnych dla instytucji związanych z zarządem „przedsiębiorstwem w spadku”, sięgnąc trzeba do rozporządzenia Parlamentu Europejskiego i Rady (UE) nr 650/2012 z dnia 4 lipca 2012 r. w sprawie jurysdykcji, prawa właściwego, uznawania i wykonywania orzeczeń, przyjmowania i wykonywania dokumentów urzędowych dotyczacych dziedziczenia oraz $\mathrm{w}$ sprawie ustanowienia europejskiego poświadczenia spadkowego ${ }^{5}$ [dalej: rozporządzenie spadkowe].

Przypomnieć więc wypada, że statut spadkowy w rozporządzeniu wyznaczaja głównie przepisy art. 21 i $22^{6}$, w art. 23 objaśniono zakres zastosowania statutu spadkowego, w art. 24 wskazano prawo właściwe dla rozrządzeń na wypadek śmierci innych niż umowy dotyczace spadku, a w art. 25 - dla umów dotyczących spadku, i wreszcie w art. 26 objaśniono pojęcie „ważności materialnej” rozrządzeń na wypadek śmierci, o których mowa w art. 24 i 25. Prawo właściwe do oceny „ważności formalnej” pisemnych rozrządzeń na wypadek śmierci określa art. 27 rozporządzenia. Przedmiotem zainteresowania będą nadto art. 29 dotyczący wyznaczenia zarządcy spadku i jego kompetencji w sytuacjach opisanych w tym przepisie oraz art. 30 stwarzający podstawę do stosowania przepisów szczególnych obowiązujących w państwie, w którym znajdują się określone w tym przepisie składniki majątku spadkowego.

roko rozumianego (szczególnego, atypowego) zastępstwa pośredniego lub jest on takiemu zastępstwu bliski. Zob. R. Blicharz: Zarzqd sukcesyjny przedsiębiorstwem $w$ spadku. Warszawa 2019, s. 37 i 38; K. Osajda, w: Kodeks cywilny. Komentarz. Spadki. T. 4A..., s. 844 i 845, Nb 73, 74; K. Kopaczyńska-Pieczniak: Status prawny zarzadcy sukcesyjnego. „Przegląd Prawa Handlowego” 2018, nr 12, s. 6 i n.; R. Kapkowski, M. Kaufmann: Charakter prawny..., s. 78; J. Bieluk: Ustawa o zarzadzie sukcesyjnym przedsiębiorstwem osoby fizycznej. Komentarz. Warszawa 2019, s. 73; A. Szereda: Przedsiębiorstwo $w$ spadku - odrębna jednostka organizacyjna. W: Notarialne poświadczenie dziedziczenia. Red. A. Marciniak. Warszawa 2019, s. 225; M. Pazdan: Zarzad sukcesyjny - aspekty kolizyjnoprawne. W: Prawo handlowe. Między teoria, praktyka a orzecznictwem. Księga jubileuszowa dedykowana Profesorowi Januszowi A. Strzępe. Red. E. Zielińska, P. Pinior, P. Relidzyński, W. Wyrzykowski, M. Żaba. Warszawa 2019, s. 69. Natomiast zdaniem M. Sieradzkiej (Zarzqd sukcesyjny przedsiębiorstwem osoby fizycznej - analiza i ocena nowych rozwiazan prawnych. Cz. 1. „Monitor Prawniczy” 2018, nr 22, s. 1198), zarząd sukcesyjny jest instytucja „odrębną” zarówno „od innych znanych form przedstawicielstwa, jak i zastępcy pośredniego”; zob. też tej samej autorki („Monitor Prawniczy” 2018, nr 23, s. 1242) porównanie zarządcy sukcesyjnego z zastępcą pośrednim.

${ }^{4}$ Odsyłam w tym miejscu do definicji „przedsiębiorstwa w spadku”, zamieszczonej w art. 2 ustawy z 2018 r. Zob. też A. Szereda: Przedsiębiorstwo w spadku..., s. 214 i n. $\mathrm{Z}$ kolei w art. 3 znalazła się definicja „właściciela przedsiębiorstwa”.

${ }^{5}$ Dz.Urz. UE 2012, L 201, s. 107 ze sprost.

${ }^{6}$ Zob. też art. 83 ust. 2-4 rozporządzenia. Szerzej na ich temat por. M. Pazdan, w: Prawo prywatne międzynarodowe. Komentarz. Red. M. Pazdan. Warszawa 2018, s. 1167 i n., i autorzy tam powołani, oraz s. 1276-1280. 
Przepis art. 23 ust. 1 rozporządzenia stanowi, że statutowi spadkowemu podlega „ogół spraw dotyczących spadku”. Zasadę przewodnią rozporządzenia stanowi więc zasada jednolitości statutu spadkowego ${ }^{7}$. Nie wyklucza to istnienia od niej odstępstw, polegających bądź na wyłączeniu określonych kwestii z zakresu zastosowania statutu spadkowego i poddaniu ich właściwości innego prawa (przypadki tzw. rozszczepienia sytuacji życiowej) ${ }^{8}$, bądź na rozczłonkowaniu statutu spadkowego (w szczególności ze względu na zawartość spadku) ${ }^{9}$. Obie postaci odstępstw od zasady jednolitości statutu spadkowego spotykamy w rozporządzeniu ${ }^{10}$.

$\mathrm{W}$ art. 23 ust. 2 rozporzadzenia zamieszczono przykładowe wyliczenie kwestii spadkowych należacych do zakresu zastosowania statutu spadkowego.

W przepisie tym, w punkcie oznaczonym lit. f, jego zasięgiem objęto „uprawnienia spadkobierców, wykonawców testamentów i innych zarządców spadku, w szczególności dotyczące sprzedaży składników majątku i zaspokojenia wierzycieli”. Zastrzeżono jednak, że nie może to prowadzić do „uszczerbku dla uprawnień, o których mowa w art. 29 ust. 2 i 3”.

Dalsze rozważania zmierzać będą do ukazania kolizyjnoprawnych podstaw właściwości i stosowania prawa merytorycznego dochodzącego do głosu przy ocenie zagadnień dotyczacych zarówno wykonawcy testamentu, jak i zarządcy sukcesyjnego. Na uwagę zasługują w szczególności: doniosłość przy ocenie tych instytucji statutu spadkowego, statutu miarodajnego dla czynności prawnospadkowych i innych statutów. Określić też trzeba podstawę i zakres stosowania przepisów ustawy o zarządzie sukcesyjnym z 2019 r.

${ }^{7} \mathrm{Na}$ jej temat oraz odstępstw od niej por. M. Pazdan: Zasada jednolitości statutu spadkowego $i$ odstęstwa od niej $w$ rozporzadzeniu spadkowym UE $z 2012$ r. W: Prawo prywatne wobec wyzwań wspótczesności. Księga pamiatkowa dedykowana Profesorowi Leszkowi Ogiegle. Red. M. Fras, P. Ślęzak. Warszawa 2017, s. 343 i n. i autorzy tam powołani.

${ }^{8} \mathrm{Na}$ temat pojęcia rozszczepienia sytuacji życiowej por. M. Pazdan: Rozszczepienie statutu kontraktowego oraz inne odstępstwa od zasady jednolitości statutu kontraktowego. „Studia Iuridica Silesiana” 1991, T. 126, s. 59 i n.; Idem: O niektórych osobliwościach poszukiwania prawa właściwego. W: „Valeat aequitas”. Księga pamiatkowa ofiarowana Księdzu Profesorowi Remigiuszowi Sobańskiemu. Red. M. Pazdan. Katowice 2000, s. 344 i n.; A. Mączyński: Wskazanie kilku praw przez normę kolizyjna prawa prywatnego międzynarodowego. W: Rozprawy z polskiego i europejskiego prawa prywatnego. Księga pamiatkowa ofiarowana Profesorowi Józefowi Skapskiemu. Red. A. Mączyński, M. Pazdan, A. Szpunar. Kraków 1994, s. 246.

${ }^{9}$ Liczne przykłady podaje J. Pazdan: Umowy dotyczqce spadku w rozporzadzeniu spadkowym Unii Europejskiej. Warszawa 2018, s. 69 i n.

${ }_{10}$ Zob. szerzej M. Pazdan: Zasada jednolitości..., s. 345 i n. 


\section{Zasięg statutu spadkowego przy ocenie wykonawcy testamentu}

$\mathrm{Z}$ art. 23 ust. 2 lit. f rozporządzenia wynika, że statut spadkowy obejmuje „uprawnienia” m.in. wykonawców testamentów. W rzeczywistości zakres zastosowania tego statutu przy ocenie wykonawcy testamentu jest o wiele szerszy.

Według postanowień statutu spadkowego należy oceniać w szczególności ${ }^{11}$ :

a) dopuszczalność ustanowienia wykonawcy testamentu;

b) kto może być wykonawca testamentu (czy tylko osoba fizyczna, czy też również osoba prawna, czy powołanie może dotyczyć jedynie takiej osoby fizycznej, która ma pełną zdolność do czynności prawnych — zob. art. $986 \S 2$ naszego k.c., i wreszcie czy wolno powołać tylko jednego, czy też wielu wykonawców testamentu);

c) sposób powołania wykonawcy testamentu (np. wymaganie powołania wykonawcy testamentu w testamencie - art. $986 \S 1$ naszego k.c.);

d) stosunek prawny powstajacy pomiędzy spadkobierca (spadkobiercami) a wykonawca (wykonawcami) testamentu (w szczególności powstanie obowiązku pełnienia funkcji wykonawcy testamentu, treść stosunku, z którego ten obowiązek wypływa, i jego ustanie);

e) zakres autonomii woli po stronie spadkodawcy przy kształtowaniu kompetencji wykonawcy testamentu;

f) kompetencje wykonawcy testamentu oraz to

${ }^{11} \mathrm{Na}$ tle polskich uregulowań krajowych prawa prywatnego międzynarodowego wypowiedzi w piśmiennictwie dotyczące wykonawcy testamentu nie były liczne. M. Soś niak (Prawo prywatne międzynarodowe. Katowice 1978, s. 238) uważał, że „ustanowienie i zakres uprawnień wykonawcy testamentu należałoby poddać statutowi testamentowemu, najbliższemu ewentualnej woli testatora"; zdaniem B. Walaszka (w: B. Walaszek, M. Sośniak: Zarys prawa międzynarodowego prywatnego. Warszawa 1973, s. 271), statut spadkowy rozstrzyga o „dopuszczalności ustanowienia wykonawcy testamentu i jego sytuacji prawnej”; według J. Gołaczyńskiego (Prawo prywatne międzynarodowe. Warszawa 2015, s. 315, Nb 497), „sytuację wykonawcy testamentu określa statut spadkowy"; M. Pazdan (Prawo prywatne międzynarodowe. Warszawa 2012 , s. 279 , Nb 544) uważał, że „pozycję prawną wykonawcy testamentu określa statut spadkowy. Ważność rozrządzenia, moca którego wykonawca testamentu został ustanowiony, jest jedna z kwestii objętych zakresem działania statutu czynności prawnych mortis causa (art. 65 ustawy z 2011 r.)"; J. Pazdan (w: Prawo prywatne międzynarodowe. Komentarz. Red. J. Poczobut. Warszawa 2017, s. 987, Nb 90) ocenę wykonawcy testamentu lub zarządcy spadku zaliczyła do zakresu zastosowania statutu spadkowego. 
g) czy wykonawca testamentu ponosi odpowiedzialność za szkodę wyrządzoną niewykonaniem lub nienależytym wykonaniem ciążących na nim obowiązów jako na wykonawcy testamentu.

W sytuacji gdy statutem spadkowym jest prawo polskie, znajdzie ono zastosowanie do wszystkich wymienionych wyżej kwestii. Wykonawca testamentu ustanowiony przez spadkodawcę może wypełniać swe funkcje nie tylko w odniesieniu do spadku położonego w Polsce, lecz również $\mathrm{w}$ innych państwach (zwłaszcza w innych państwach członkowskich). Trudności mogą się jednak pojawić w sytuacji, gdy jurysdykcyjnie właściwe $\mathrm{w}$ sprawie spadkowej sa sądy państwa członkowskiego, a prawo spadkowe tego państwa jest oparte na odmiennych założeniach niż prawo, które jest statutem spadkowym. Do tego może dojść wtedy, gdy jurysdykcja oparta jest na łączniku miejsca zwykłego pobytu spadkodawcy z chwili śmierci (art. 4), a w roli statutu spadkowego dzięki wyborowi prawa występuje prawo ojczyste (art. 22). Moga w takiej sytuacji być spełnione przesłanki określone w art. 29 ust. 1 rozporządzenia. Otwiera to droge do ustanowienia na podstawie tego przepisu zarządcy spadku w państwie członkowskim, którego sądy są jurysdykcyjnie właściwe. Przepis ten zaleca, by na zarządce powołać „osobę uprawnioną do wykonywania testamentu zmarłego lub zarządzania spadkiem na podstawie prawa właściwego dla dziedziczenia" (art. 29 ust. 1 al. 2). W art. 29 ust. 2 rozporządzenia znajduje się szereg wskazówek zmierzających do usunięcia stanu napięcia pomiędzy prawem obowiązującym w siedzibie sądu jurysdykcyjnie właściwego w sprawie spadkowej (i do którego sprawę wniesiono) a obcym dla tego sądu statutem spadkowym. Sądowi wyznaczającemu zarządce przyznano $\mathrm{w}$ tym przepisie dodatkowe kompetencje do ukształtowania uprawnień zarządcy.

\section{Prawo właściwe dla zarządu sukcesyjnego}

Wraz z wejściem w życie w naszym kraju ustawy o zarządzie sukcesyjnym z 2018 r. pojawiło się pytanie, czy jej przepisy należy objąc zakresem zastosowania statutu spadkowego, stosować je więc wtedy, gdy w roli tego statutu występuje prawo polskie, czy też poszukiwać innego rozwiąania.

Miałem już okazję wyrażenia w tej sprawie własnego poglądu ${ }^{12}$. Przy poglądzie tym obstaję. Kolizyjnoprawnej podstawy stosowania przepisów

${ }_{12}$ Zob. M. Pazdan: Zarzqd sukcesyjny - aspekty kolizyjnoprawne..., s. 73 i n. 
ustawy o zarządzie sukcesyjnym upatruję mianowicie w art. 30 rozporządzenia UE nr 650/2012.

Przepisy ustawy o zarządzie sukcesyjnym z 2018 r. maja charakter przepisów szczególnych modyfikujących z powodów określonych w art. 30 rozporządzenia (względy ekonomiczne i społeczne) zarząd spadkiem $\mathrm{w}$ takim zakresie, $\mathrm{w}$ jakim dotyczy on przedsiębiorstwa wchodzacego do spadku („przedsiębiorstwa w spadku”). Bez watpienia nie chodzi tu o pierwsza grupe sytuacji przewidzianych w art. 30, czyli o ograniczenie dziedziczenia przedsiębiorstwa, lecz o grupę druga, która obejmuje sytuacje, gdy dochodzi jedynie do „wpływania na dziedziczenie”. Zarząd przedsiębiorstwem wchodzącym do spadku przewidziany ustawa z 2018 r. ma zapobiegać rozpadowi przedsiębiorstwa po śmierci przedsiębiorcy. Ustawa zmierza zatem do ochrony przedsiębiorstwa na wypadek śmierci przedsiębiorstwa. W gruncie rzeczy chodzi o to, aby przedsiębiorstwo zachowane w całości weszło do spadku i zostało nabyte w drodze dziedziczenia przez spadkobiercę (spadkobierców) lub na podstawie zapisu windykacyjnego przypadło zapisobiercy windykacyjnemu.

Przepisy ustawy z 2018 r. znajdują zastosowanie wyłącznie do „przedsiębiorstwa w spadku” (w rozumieniu przyjętym w art. 2 ustawy), należącego do przedsiębiorcy, będącego osobą fizyczna, który we własnym imieniu prowadzi działalność gospodarcza na podstawie wpisu do Centralnej Ewidencji Informacji o Działalności Gospodarczej (CEDIG). Sa więc $\mathrm{w}$ ten swoisty sposób powiązane z terytorium Polski. Do zastosowania przepisów ustawy może więc dojść zarówno wtedy, gdy statutem spadkowym jest prawo polskie, jak i wtedy, gdy jest nim prawo obce.

To, że statutem spadkowym jest prawo polskie, nie stwarza wystarczającej podstawy do ich stosowania. Nie sa bowiem objęte zakresem zastosowania tego statutu. Brak również podstawy do ich stosowania, gdy przedsiębiorstwo wchodzace do spadku znajduje się za granica, jeśli nawet statutem spadkowym jest prawo polskie.

Przepis art. 30 rozporządzenia uzasadnia oczekiwanie, że w sytuacji, gdy przedsiębiorstwo należące do spadku znajduje się w Polsce, a sprawę spadkową rozpatruje sąd w innym państwie członkowskim (co w świetle art. 4 i n. rozporządzenia nie jest wykluczone), są ten (i inne organy w tym państwie) respektować będzie kompetencje zarządcy sukcesyjnego względem wchodzącego do spadku przedsiębiorstwa znajdującego się w Polsce. Chodzić tu może m.in. o pojedyncze składniki majątku przedsiębiorstwa powiązanego w opisany wyżej sposób z Polską, znajdujące się za granica (np. towary, walory na kontach bankowych).

Odnieść to można także do kompetencji do zarządu przedsiębiorstwem w spadku przyznanych w art. 13 ustawy z 2018 r. osobom wymienionym $\mathrm{w}$ art. 14 tego aktu na czas od chwili śmierci przedsiębiorcy do 
dnia ustanowienia zarządu sukcesyjnego (lub gdy zarządcy nie ustanowiono do dnia wygaśnięcia uprawnienia do jego powołania).

Truizmem jest stwierdzenie, że postanowienia ustawy o zarządzie sukcesyjnym z 2018 r. należy stosować do kwestii w niej uregulowanych. Dotyczy to w szczególności przepisów normujących powołanie, funkcjonowanie (m.in. kompetencje zarządcy sukcesyjnego, jego prawa i obowiązki) i wygaśnięcie funkcji zarządcy sukcesyjnego.

\section{Statut spadkowy a prawo właściwe dla zarządu sukcesyjnego}

Zarówno wtedy, gdy spadkodawca ustanowił wykonawcę testamentu, jak i wtedy, gdy doszło do powołania zarządcy sukcesyjnego, zakres zastosowania statutu spadkowego w odniesieniu do głównych kwestii prawnospadkowych jest podobny. Zbędne jest ich wyliczanie w tym miejscu.

Dotyczy to także losów przedsiębiorstwa należącego do spadku. Według postanowień statutu spadkowego należy oceniać m.in. dziedziczenie ustawowe przedsiębiorstwa, jego dziedziczenie testamentowe lub nabycie na podstawie zapisu windykacyjnego.

Różnice występują natomiast przy ocenie rozważanych tu instytucji zarządu spadkiem (przedsiębiorstwem). Instytucja wykonawcy testamentu - o czym już była mowa - objęta jest zakresem zastosowania statutu spadkowego. Natomiast zarząd sukcesyjny przedsiębiorstwa podlega odrębnemu prawu. Jest to prawo państwa miejsca położenia przedsiębiorstwa, stosowane na podstawie art. 30 rozporządzenia. Jego dojście do głosu jest zbliżone do sposobu działania przepisów wymuszających swoje zastosowanie $^{13}$.

Zapewnia to przewagę tych przepisów nad postanowieniami statutu spadkowego. W razie więc powołania przez spadkodawcę zarówno wykonawcy testamentu, jak i zarządcy sukcesyjnego przy ocenie ich stosunku do siebie pierwszeństwo należy przyznać przepisom ustawy o zarządzie sukcesyjnym.

Na uwage w tym kontekście zasługuje art. 24 ustawy z 2018 r. Stanowi on, że w razie ustanowienia zarządu sukcesyjnego zarząd spadkiem

${ }_{13}$ M.A. Zachariasiewic z: Przepisy wymuszajace swoje zastosowanie a statut spadkowy. W: Nowe europejskie prawo spadkowe. Red. M. Pazdan, J. Górecki. Warszawa 2015, s. 318; M. Mataczyński: Przepisy wymuszajace swoje zastosowanie - wybrane zagadnienia. „Problemy Prawa Prywatnego Międzynarodowego” 2016, T. 18, s. 73 i n. 
sprawowany przez wykonawcę testamentu nie obejmuje przedsiębiorstwa w spadku.

Przepis ten nie usuwa jednak wszystkich wątpliwości. Na jego podstawie należy przyjąć, że w sytuacji, gdy spadkodawca powołał wykonawcę testamentu o ogólnych kompetencjach i zarządcę sukcesyjnego, zarząd przedsiębiorstwem jest wyłączony z kompetencji wykonawcy testamentu przez czas trwania zarządu sukcesyjnego ${ }^{14}$.

Nasuwa się pytanie, czy podobne rozwiazanie jest uzasadnione w razie powołania przez spadkodawcę najpierw wykonawcy testamentu z kompetencjami ograniczonymi do zarzadu przedsiębiorstwem, a następnie zarządcy sukcesyjnego tego samego przedsiębiorstwa.

Bronić można poglądu, że w takim przypadku wykonawcy testamentu wolno wykonywać swoje kompetencje dopiero po wygaśnięciu zarzadu sukcesyjnego, chyba że wcześniej dojdzie do objęcia przedsiębiorstwa przez właściwego beneficjariusza spadkowego (spadkobiercę lub zapisobiercę windykacyjnego).

\section{Kwestie niepodlegające prawu właściwemu dla wykonawcy testamentu lub zarządu sukcesyjnego}

5.1. Wspomniano już wyżej, że z postanowień prawa właściwego dla wykonawcy testamentu (czyli statutu spadkowego) może wynikać wymaganie powołania wykonawcy testamentu w testamencie. Nie oznacza to poddania w takim przypadku w całej rozciagłości testamentu statutowi spadkowemu. Także wtedy, gdy w testamencie znalazło się powołanie wykonawcy testamentu (jeśli nawet jest to jedyne rozrządzenie spadkodawcy zamieszczone $\mathrm{w}$ testamencie), ważność testamentu podlega ocenie na podstawie prawa wskazanego przez odrębne normy kolizyjne (art. 24 rozporządzenia w odniesieniu do „ważności materialnej testamentu; w Polsce i w większości państw członkowskich postanowienia konwencji haskiej dotyczącej kolizji praw w przedmiocie rozporządzeń testamentowych z $1961 \mathrm{r}^{15}{ }^{15}$ $\mathrm{w}$ odniesieniu do wymagań dotyczacych formy). Jeżeli testament w świetle praw, którym podlega (zarówno w zakresie „ważności materialnej”, jak i formy), jest ważny, jego skutki - m.in. dotyczace powołania wykonawcy testamentu — oceniać należy według postanowień statutu spadkowego.

${ }_{14}$ Zob. szerzej M. Pazdan: Zarzadca sukcesyjny a wykonawca testamentu..., s. 893; P. Pacek: Wykonawca testamentu a zarzad sukcesyjny..., s. 54 i n.

15 Dz.U. 1969, nr 34, poz. 284. 
5.2. Nie ma też potrzeby poszukiwania prawa właściwego do oceny zdolności do powołania wykonawcy testamentu. Wystarczy odszukać prawo właściwe do oceny zdolności testowania (zdolności do sporządzenia ważnego testamentu), tę zaś w obrębie czynności prawnych objętych zakresem zastosowania normy kolizyjnej z art. 24 rozporządzenia należy oceniać według prawa wskazanego przez ten przepis (art. 26 ust. 1 lit. a rozporządzenia) ${ }^{16}$.

5.3. Zdolność do czynności prawnych występuje w prawie prywatnym w różnych rolach ${ }^{17}$. Obok jej najważniejszej funkcji jako przesłanki ważności lub skuteczności czynności prawnej, spełnia jeszcze inne funkcje. Wpływa na przykład na upływ terminu przedawnienia (zob. art. 121 pkt 2 polskiego k.c.) lub występuje w roli przesłanki skuteczności działania przedstawiciela. Bywa też wykorzystywana jako okoliczność, od której zależy możność pełnienia przez osobę fizyczną określonych funkcji (zajęcia określonego stanowiska).

W naszym prawie zarówno od wykonawcy testamentu (art. 986 $\S 2$ k.c.), jak i od zarządcy sukcesyjnego wymaga się pełnej zdolności do czynności prawnych (art. 8 ust. 1 ustawy z 2018 r.). Pełna zdolność do czynności prawnych stanowi więc w tym przypadku przesłankę dopuszczalności pełnienia przez daną osobę funkcji wykonawcy testamentu lub zarządcy sukcesyjnego.

5.4. Prawa właściwego do ustalenia kwalifikacji personalnych wymaganych do zajęcia określonego stanowiska (pełnienia określonych funkcji) poszukiwać należy w prawie, któremu podlega instytucja, z która wiąże się zajęcie tego stanowiska ${ }^{18}$.

W rozważanym zakresie może to być albo prawo właściwe dla instytucji wykonawcy testamentu, albo prawo, któremu podlega zarząd sukcesyjny.

W pierwszym przypadku jest to statut spadkowy, natomiast $\mathrm{w}$ drugim - prawo polskie (ustawa o zarządzie sukcesyjnym z 2018 r.).

$\mathrm{Na}$ podstawie tych przepisów należy więc określić m.in. stopień wymaganej zdolności do czynności prawnych do zajęcia stanowiska, o które chodzi.

${ }_{16}$ Zob. M. Pazdan, w: Prawo prywatne międzynarodowe. Komentarz..., s. 1210 i n., $\mathrm{Nb} 9$.

${ }_{17}$ Zob. M. Pazdan: O różnych funkcjach zdolności do czynności prawnych osoby fizycznej z uwzględnieniem aspektów arbitrażowych i kolizyjnoprawnych. W: Prawo prywatne $i$ arbitra $\dot{z}$. Księga jubileuszowa dedykowana doktorowi Maciejowi Tomaszewskiemu. Red. J. Poczobut, A.W. Wiśniewski. Warszawa 2016, s. 269 i n.

${ }_{18}$ Zob. M. Pazdan, w: Prawo prywatne międzynarodowe. Komentarz..., s. 58, Nb 37. 
5.5. Oddzielnym zadaniem jest poszukiwanie prawa właściwego do oceny zdolności do czynności prawnych danej osoby, a więc m.in. do udzielenia odpowiedzi na pytanie, czy dana osoba ma pełna lub ograniczona zdolność do czynności prawnych, czy też tej zdolności nie ma.

Zdolność do czynności prawnych jako przesłanka ważności lub skuteczności czynności prawnej traktowana jest jako kwestia cząstkowa (wycinkowa) stanu faktycznego (sytuacji życiowej), obejmujaceego czynność prawną. Dochodzi wówczas do równoległego (równorzędnego) wskazania prawa właściwego dla kwestii czastkowej (w rozpatrywanym przypadku zdolności do czynności prawnych) i sprawy głównej (stanowi ja czynność prawna) ${ }^{19}$. Prawa właściwego dla kwestii cząstkowej należy poszukiwać na podstawie odrębnych norm kolizyjnych, miarodajnych dla instytucji prawnej występującej $\mathrm{w}$ roli kwestii czastkowej, obowiązujacych w państwie, w którym dokonywana jest ocena ${ }^{20}$.

5.6. Wymaganie pełnej zdolności do czynności prawnych do zajęcia określonego stanowiska nie ma charakteru kwestii cząstkowej. Na płaszczyźnie kolizyjnoprawnej zasługuje więc na odrębne rozpatrzenie.

Bronię stanowiska, że stanowi ono kwestię wstępna ${ }^{21}$, rozwiązywana w sposób przyjęty dla kwestii wstępnych ${ }^{22}$.

${ }_{19}$ Zob. M. Pazdan, w: „System Prawa Prywatnego”. T. 20A: Prawo prywatne międzynarodowe. Red. M. Pazdan. Warszawa 2014, s. 341 i 342, Nb 10.

${ }_{20}$ Zob. M. Pazdan, w: Prawo prywatne międzynarodowe. Komentarz..., s. 189, Nb 67; Idem, w: „System Prawa Prywatnego”. T. 20A [2014], s. 342, Nb 10.

${ }^{21}$ Zob. M. Pazdan, w: Prawo prywatne międzynarodowe. Komentarz..., s. 189, Nb 68.

${ }_{22}$ Zob. G. Melchior: Die Grundlagen des deutschen internationalen Privatrechts. Berlin 1932, s. 245 i n.; W. Wengler: Die Vorfrage im Kollisionsrecht, Zeitschrift für ausländisches und internationales Privatrecht. „Rabels Zeitschrift für ausländisches und internationales Privatrecht" 1934, s. 148 i n.; A. Makarov: Les cas d'application des règles de conflit étrangéres, Revue critique de droit international privé. „Revue critique de droit international privé" 1955, s. 431 i n.; P. Lagarde: La règle de conflit applicable aux questions préalables. „Revue critique de droit international privé” 1961, s. 459 i n.; W. Wengler: Nouvelles réflexions sur les „questions préalables”. „Revue critique de droit international privé" 1966, s. 165 i n.; A.E. Gotlieb: The incidental question revisited theory and practice in the conflict of laws. „International and Comparative Law Quarterly" 1977, vol. 26 Oct., s. 734 i n.; T.S. Schmidt: The incidental question on private international law. „Recueil des Cours” 1992, II (T. 233), s. 315 i n.; D. Solomon: Die Anknüpfung von Vorfragen im Europäischen Internationalen Privatrecht. In: Fastschrift für Ulrich Spellenberg. Hrsg. J. Bernreuther, R. Freitag, S. Leible, H. Sippel, U. Wanitzek. Sellier 2010, s. 355 i n.; S.L. Goess s: Preliminary questions in EU private international law. „Journal of Private International Law” 2012, vol. 8, no. 1, s. 63 i n.; P. Rodziewicz: Stwierdzenie treści oraz zastosowanie prawa obcego w sadowym postępowaniu cywilnym. Warszawa 2015, s. 166 i n.; M. Pazdan: Stosowanie obcych norm kolizyjnych. „Problemy Prawa Prywatnego Międzynarodowego” 2016, T. 18 , s. 25 i n. 
Opowiadam się za poszukiwaniem prawa właściwego dla kwestii wstępnej - w zależności od okoliczności danego stanu faktycznego albo według kolizyjnej legis fori, albo kolizyjnej legis causae ${ }^{23}$.

$\mathrm{W}$ odniesieniu do wykonawcy testamentu prawem (statutem spadkowym), na tle którego wymaganie zdolności kandydata na wykonawcę testamentu się pojawia, może być bądź prawo polskie, bądź prawo obce. Wydaje się, że wiele przemawia za tym, aby przy ustalaniu prawa właściwego dla zdolności jako kwestii wstępnej w powiązaniu z wykonawca testamentu posługiwać się normami kolizyjnymi miarodajnymi dla zdolności, wchodzącymi w skład systemu prawnego, który zrodził potrzebę poszukiwania rozstrzygnięć dotyczacych zdolności. W rozpatrywanych przypadkach chodzi o normy kolizyjne miarodajne dla zdolności, wyznaczajace statut personalny osoby, obowiąujące w państwie, którego prawo stanowi statut spadkowy. Jeżeli więc statutem spadkowym jest prawo polskie, prawa właściwego do oceny zdolności wymaganej od kandydata na wykonawcę testamentu (jako kwestii wstępnej) należy poszukiwać, stosując art. 11 ustawy z 2011 r. Jeżeli zaś statutem spadkowym jest prawo innego państwa, do oceny zdolności w rozpatrywanym zakresie należy zastosować prawo wskazane przez normy kolizyjne miarodajne dla zdolności obowiąujące w tym innym państwie.

Sytuacja przedstawia się zgoła inaczej przy rozpatrywaniu zdolności wymaganej od kandydata na zarządcę sukcesyjnego. Zarząd sukcesyjny — jak już była o tym mowa - podlega zasadniczo prawu polskiemu. Trzeba się więc liczyć - w przypadku kandydata na zarządcę sukcesyjnego - jedynie z kwestiami wstępnymi pojawiającymi się na tle merytorycznego prawa polskiego. Przy ich rozstrzyganiu będa więc wykorzystywane normy kolizyjne obowiązujace w Polsce, miarodajne dla kwestii występujacych w roli kwestii wstępnych.

Nie ulega watpliwości, że przedsiębiorca (lub inna osoba określona w art. 14 ustawy z 2018 r.) może powołać na zarządcę sukcesyjnego przedsiębiorstwa położonego w Polsce także cudzoziemca. Odpowiedzi na pytanie, czy kandydat na zarządce ma wymaganą przez art. 8 ustawy z 2018 r. pełną zdolność do czynności prawnych, trzeba poszukiwać w postanowieniach jego statutu personalnego ustalonego na podstawie art. 11 ust. 1 ustawy o prawie prywatnym międzynarodowym z 2011 r.

${ }^{23}$ Zob. A.E. Gotlieb: The incidental question in Anglo-American conflict of laws. „The Canadian Bar Review” 1955, vol. 33, s. 555; Dicey`s Conflict of Laws. Ed. J.H.C. Mor ris. London 1958, s. 62 i n.; w polskim piśmiennictwie M. Sośniak: Prawo..., s. 67 i n.; M. Pazdan, w: „System Prawa Prywatnego”. T. 20A [2014]..., s. 345 i 346, Nb 23; M. Pilich: Zasada obywatelstwa $w$ prawie prywatnym międzynarodowym. Zagadnienia podstawowe. Warszawa 2015, s. 484 i n.; J. Poczobut, A.W. Wiśniewski, w: Prawo prywatne międzynarodowe. Komentarz. Red. J. Poczobut..., s. 121 i 122, Nb 118. 
5.7. Z art. 2 ust. 2 ustawy z 2018 r. wynika, że jeżeli w chwili śmierci przedsiębiorcy przedsiębiorstwo stanowi w całości mienie przedsiębiorcy i jego małżonka, przedsiębiorstwem w spadku jest całe to przedsiębiorstwo.

Przepis ten należy interpretować szeroko. Zwrot „przedsiębiorstwo stanowi mienie przedsiębiorcy i jego małżonka” obejmuje zarówno taka sytuację, w której małżonkowie pozostaja we wspólności majątkowej małżeńskiej, a przedsiębiorca jest tylko jeden małżonek, jak i taka, gdy przedsiębiorcami sa oboje małżonkowie. Zwrot ten obejmuje również sytuację, w której małżonkowie pozostający w reżimie odrębności majątkowej małżeńskiej sa jedynymi wspólnikami spółki cywilnej, w ramach której prowadzą przedsiębiorstwo.

O tym, czy przedsiębiorstwo należy do majątku osobistego jednego z małżonków, czy też do ich majątku wspólnego, rozstrzyga prawo właściwe dla stosunków majątkowych małżeńskich. W Polsce należy je ustalać na podstawie art. 51 lub 52 ustawy o prawie prywatnym międzynarodowym z 2011 r. ${ }^{24}$ Prawem właściwym, wskazanym przez te przepisy, może być bądź prawo polskie, bądź prawo obce.

Różnorodność spółek cywilnych jest źródłem trudności przy ustalaniu prawa dla nich właściwego.

Przewidziane w art. 1 ust. 2 lit. f rozporządzenia Rzym I wyłączenie z zakresu zastosowania tegoż rozporządzenia „kwestii z zakresu prawa spółek i innych podmiotów posiadających osobowość prawną lub jej nieposiadających" nie odnosi się do tzw. wewnętrznych spółek prawa cywilnego (Innengesellschaften), spółek cichych czy też tzw. spółek okolicznościowych (Gelegénheitsgesellschaften), powoływanych dla określonych celów (np. konsorcjów). Dla nich prawo właściwe należy ustalać, stosując rozporządzenie Rzym I (art. 3 oraz art. 4 ust. 2 i 3$)^{25}$. Jest też oczywiste,

${ }^{24}$ Zob. P. Twardoch, w: „System Prawa Prywatnego”. T. 22C [2015]..., s. 115 i n., $\mathrm{Nb} 38$ i n.

${ }_{25}$ Zob. U. Magnus, in: J. von Staudingres Kommentar zum Bürgerlichen Gesetbuch mit Einführungsgesetz und Nabengesetzen. Einleitung zum Rom I-VO. Red. U. Magnus. Berlin 2011, s. 79, Nb 80; E.-M. Kieniger, in: Internationales Vertragsrecht. Rom I-VO. CISG. CMR. Fact Ü. Kommentar. Red. F. Ferrari et al. München 2012, s. 16, Nb 21; R. Hausmann, in: Internationales Vertragsrecht. Hrsg. Ch. Reithmann, D. Martiny. Kóln 2015, s. 1620 i 1621, Nb 7.148; G. Hohloch, in: Erman, Bürgerliches Gesetzbuch. Handkommentar. Hrsg. H.P. Westermann, B. Grunewald, G. Maier-Reimer. Köln 2017, s. 6841, Nb 10; D. Martiny, in: Münchener Kommentar zum Bürgerlichen Gesetzbuch. Bd. 12. Red. J. von Hein. München 2018, s. 69, Nb 71 i 72. Por. też propozycję M. Pazdana (w: Prawo spółek handlowych. T. 2A. Red. A. Szumański. Warszawa 2019, s. 356, Nb 21), by w odniesieniu do spółek cywilnych, którym ich potencjalny statut personalny przyznaje osobowość prawną lub przynajmniej zdolność prawną, zwracać się wprost do ich statutu personalnego. W takich przypadkach zastosowanie rozporządzenia Rzym I byłoby wyłączone. 
co potwierdza art. 1 ust. 2 lit. h rozporządzenia spadkowego, że o dziedziczności udziału w spółkach zarówno mających osobowość prawna, jak i majacych jedynie zdolność prawną rozstrzyga prawo dla nich właściwe, czyli ich statut personalny. Jeśli odmawia im dziedziczności, samo decyduje o ich losach na wypadek śmierci wspólnika. Jeżeli przyznaje im przymiot dziedziczności, o ich dziedziczeniu rozstrzyga statut spadkowy ustalony na podstawie rozporządzenia spadkowego.

5.8. Ustanowienie zarządu sukcesyjnego wymaga złożenia przez różne podmioty określonych oświadczeń: a) oświadczenia o powołaniu zarządcy sukcesyjnego złożonego przez przedsiębiorcę (art. 9 ustawy z 2018 r.) lub osoby wymienione w art. 14 ustawy z 2018 r.; b) wyrażenia zgody przez osobę powołaną na zarządcę sukcesyjnego na pełnienie tej funkcji (art. 6 ust. 1 pkt 2 ustawy z 2018 r.); c) wyrażenia zgody na powołanie zarządcy sukcesyjnego osób, którym łącznie przysługuje udział w przedsiębiorstwie w spadku większy niż 85/100 w sytuacji, gdy do powołania zarządcy sukcesyjnego ma dojść po śmierci przedsiębiorcy.

Oświadczenia te mają charakter oświadczeń woli. Oświadczenie o powołaniu zarządcy sukcesyjnego bywa zaliczane do jednostronnych czynności prawnych, należących do rodziny czynności upoważniających ${ }^{26}$.

Bez trudu na podstawie przepisów ustawy można ustalić wymagania dotyczące zdolności do czynności prawnych jako przesłanki ważności tych oświadczeń (zob. art. 12 ust. 5 ustawy) czy też wymagania w zakresie formy (art. 9 ust. 2 , art. 12 ust. 7 ustawy).

Nie są to jednak regulacje wyczerpujące. Niezbędne jest więc sięgnięcie do przepisów księgi I polskiego kodeksu cywilnego, w celu dopełnienia regulacji zamieszczonej w ustawie, na zasadzie „wessania” odpowiednich postanowień kodeksu cywilnego. W przypadku formy będzie to unormowanie kwestii związanych $\mathrm{z}$ dopełnieniem poszczególnych wymagań w zakresie formy oraz skutków niedopełnienia tych wymagań.

W ustawie z 2018 r. nie uregulowano wad oświadczeń woli pod względem omawianych oświadczeń. Także tę lukę należy wypełniać, stosując odpowiednio przepisy o wadach oświadczenia woli znajdujące się w polskim kodeksie cywilnym (art. 82-88). W uzasadnieniu stosowania w omawianym zakresie polskich przepisów można odwołać się do bronionej w tych rozważaniach koncepcji wsysania regulacji prawnej bądź powołać się na wskazówkę z art. 67 ustawy o prawie prywatnym międzynarodowym z 2011 r. dotycząca wypełniania luk ${ }^{27}$.

${ }^{26}$ Zob. R. Blicharz: Zarzad sukcesyjny..., s. 13.

${ }^{27}$ Zob. M. Pazdan, w: Prawo prywatne międzynarodowe. Komentarz..., s. 546 i n., Nb. 5 i n.; Idem: Zarzad sukcesyjny — aspekty kolizyjnoprawne..., s. 76. 


\section{0 zjawisku wsysania regulacji prawnych}

Unormowanie instytucji wykonawcy testamentu w przepisach prawa spadkowego zwykle nie jest wyczerpujące. Pojawia się więc potrzeba wykraczania poza przepisy prawa spadkowego przy rozstrzyganiu różnych kwestii związanych z ustanowieniem i funkcjonowaniem wykonawcy testamentu.

Na przykład w myśl art. $989 \S 1$ polskiego k.c. do wzajemnych roszczeń między spadkobierca a wykonawcą testamentu, wynikających ze sprawowania zarządu (czyli do powstającego między nimi stosunku obligacyjnego), stosować należy odpowiednio przepisy o zleceniu za wynagrodzeniem.

Na tle stanów faktycznych w całości powiązanych z polskim obszarem prawnym nie ma wątpliwości, że art. $989 \S 1$ k.c. odsyła do przepisów polskiego kodeksu cywilnego o zleceniu, czyli do art. 734 i n. k.c.

$\mathrm{W}$ razie pojawienia się $\mathrm{w}$ stanie faktycznym elementu obcego nasuwa się pytanie, czy odwołanie się w postanowieniach prawa spadkowego (statutu spadkowego) do unormowania zlecenia w przepisach prawa zobowiązań kieruje stosującego prawo do unormowania zlecenia wchodzącego w skład tego systemu prawnego, którego składnikiem sa postanowienia statutu spadkowego, czy też do prawa właściwego dla umowy zlecenia, ustalonego na podstawie reguł wskazujących prawo właściwe dla zobowiązań umownych (oznaczałoby to zastosowanie rozporządzenia Rzym I). Opowiadam się za pierwszym rozwiązaniem.

Zjawisko, z którym w takim przypadku mamy do czynienia, nazywam wsysaniem do regulacji instytucji wykonawcy testamentu znajdującej się $\mathrm{w}$ postanowieniach statutu spadkowego, w celu uzupełnienia tej regulacji unormowaniami spoza prawa spadkowego, zaczerpniętymi z tego samego systemu prawnego, którego składnikiem jest statut spadkowy.

W podobny sposób uzasadniać można stosowanie art. 471 k.c. do odpowiedzialności wykonawcy testamentu $\mathrm{w}$ razie niewykonania lub nienależytego wykonania ciążących na nim obowiązków (jako wykonawcy testamentu), jeśli założy się kontraktowy charakter stosunku obligacyjnego powstającego między wykonawcą testamentu a spadkobierca (spadkobiercami $^{28}$.

Tego sposobu postępowania nie można rozciagać na ewentualną odpowiedzialność deliktową wykonawcy testamentu za szkodę wyrządzona czynem niedozwolonym przy okazji wykonywania funkcji wykonawcy te-

${ }^{28}$ Zob. M. Pazdan, w: Kodeks cywilny. T. 2: Komentarz. Art. 450-1088. Przepisy wprowadzajace. Red. K. Pietrzykowski. Warszawa 2018, s. 1172, art. 989, Nb. 1. 
stamentu. Prawa dla niej właściwego poszukiwać należy, stosując postanowienia rozporządzenia Rzym $\mathrm{II}^{29}$.

Opisane wyżej zjawisko wsysania regulacji prawnej występuje także na tle przepisów ustawy o zarządzie sukcesyjnym z 2018 r. Ustawę tę $\mathrm{w}$ takiej mierze, w jakiej reguluje ona zarząd sukcesyjny, należy stosować do kwestii w niej uregulowanych. Niektóre kwestie objęte regulacja ustawy nie zostały w niej unormowane wyczerpujacco.

Przykład stanowi art. 26 ustawy z 2018 r., nakazujący stosowanie do wynagrodzenia zarządcy sukcesyjnego odpowiednio przepisów polskiego kodeksu cywilnego o zleceniu. Nie ma tu znaczenia ewentualne występowanie $\mathrm{w}$ danym stanie faktycznym elementu obcego, ze względu na który statutem spadkowym jest prawo innego państwa (w sytuacji, gdy „przedsiębiorstwo w spadku” znajduje się w Polsce).

Z kolei w art. 34 ustawy, dotyczącym sytuacji, gdy zarządcę sukcesyjnego powołano z naruszeniem art. 12, nakazano stosować odpowiednio przepisy polskiego kodeksu cywilnego o prowadzeniu cudzych spraw bez zlecenia.

W razie stanu faktycznego z elementem obcym w pierwszym przypadku nie wchodzi więc $\mathrm{w}$ grę sięganie w celu znalezienia prawa właściwego dla zlecenia do rozporządzenia Rzym I, a w drugim przypadku nie jest uzasadnione zwrócenie się w celu odszukania prawa właściwego dla prowadzenia cudzych spraw bez zlecenia do rozporządzenia Rzym II ${ }^{30}$.

$\mathrm{W}$ tych przypadkach o wsysaniu regulacji prawnych przesądził sam ustawodawca.

\section{Bibliografia}

Bieluk J.: Ustawa o zarzadzie sukcesyjnym przedsiębiorstwem osoby fizycznej. Komentarz. Warszawa 2019.

Blajer J.: Nabycie przedsiębiorstwa będqcego przedmiotem zapisu windykacyjnego. Warszawa 2016.

Blicharz R.: Zarzqd sukcesyjny przedsiębiorstwem w spadku. Warszawa 2019.

${ }^{29}$ Rozporządzenie (WE) nr 864/2007 Parlamentu Europejskiego i Rady z dnia 11 lipca 2007 r. dotyczace prawa właściwego dla zobowiązań pozaumownych (Rzym I). Dz.Urz. UE L 2007, nr 199, s. 40.

${ }^{30}$ W tym kierunku M. Pazdan: Zarzad sukcesyjny - aspekty kolizyjnoprawne..., s. 77 . 
Dadańska K.A.: Sukcesja przedsiębiorstw — „de lege lata” $i$ „de lege ferenda”. W: Prawo rodzinne i spadkowe wobec współczesnych zjawisk technologicznych $i$ społecznych. Red. J.M. Łukasiewicz, M. Załucki. Toruń 2018.

Dicey's Conflict of Laws. Ed. J.H.C. Morris. London 1958.

Głowacz J.: Wykonawca testamentu w prawie polskim na tle porównawczym. Poznań 2018.

Goessl S.L.: Preliminary questions in EU private international law. „Journal of Private International Law" 2012, vol. 8, no. 1.

Gołaczyński J.: Prawo prywatne międzynarodowe. Warszawa 2015.

Gotlieb A.E.: The incidental question in Anglo-American conflict of laws. „The Canadian Bar Review” 1955, vol. 33.

Gotlieb A.E.: The incidental question revisited theory and practice in the conflict of laws. „International and Comparative Law Quarterly” 1977, vol. 26 Oct.

Górecki J.: Zapis windykacyjny w praktyce notarialnej. „Rejent” 2012, nr 4.

Hausmann R., in: Internationales Vertragsrecht. Hrsg. Ch. Reithmann, D. Martiny. Köln 2015.

Hohloch G., in: Erman, Bürgerliches Gesetzbuch. Handkommentar. Hrsg. H.P. Westermann, B. Grunewald, G. Maier-Reimer. Kőln 2017.

Kapkowski R., Kaufmann M.: Charakter prawny zarzadcy sukcesyjnego na tle pokrewnych instytucji zarzadu masa spadkowa. „Rejent” 2019, nr 7.

Kieniger E.-M., in: Internationales Vertragsrecht. Rom I-VO. CISG. CMR. Fact Ü. Kommentar. Red. F. Ferrari et al. München 2012.

Kopaczyńska-Pieczniak K.: Status prawny zarzadcy sukcesyjnego. „Przegląd Prawa Handlowego" 2018, nr 12.

Księżak P.: Zapis windykacyjny. Warszawa 2012.

Lagarde P.: La règle de conflit applicable aux questions préalables. „Revue critique de droit international privé” 1961.

Magnus U., in: J. von Staudingres Kommentar zum Bürgerlichen Gesetbuch mit Einführungsgesetz und Nabengesetzen. Einleitung zum Rom I-VO. Red. U. Magnus. Berlin 2011.

Makarov A.: Les cas d'application des règles de conflit étrangéres, Revue critique de droit international privé. „Revue critique de droit international privé" 1955.

Martiny D., in: Münchener Kommentar zum Bürgerlichen Gesetzbuch. Bd. 12. Red. J. von Hein. München 2018.

Mataczyński M.: Przepisy wymuszajace swoje zastosowanie - wybrane zagadnienia. „Problemy Prawa Prywatnego Międzynarodowego” 2016, T. 18.

Mączyński A.: Wskazanie kilku praw przez norme kolizyjna prawa prywatnego międzynarodowego. W: Rozprawy z polskiego i europejskiego prawa prywatnego. Księga pamiatkowa ofiarowana Profesorowi Józefowi Skapskiemu . Red. A. Mączyński, M. Pazdan, A. Szpunar. Kraków 1994.

Melchior G.: Die Grundlagen des deutschen internationalen Privatrechts. Berlin 1932 .

Osajda K.: Kodeks cywilny. Komentarz. Spadki. T. 4A. Warszawa 2019. 
Pacek P.: Wykonawca testamentu a zarzad sukcesyjny przedsiębiorstwem osoby fizycznej - wybrane zagadnienia. „Rejent” 2019, nr 6.

Pazdan J.: Umowy dotyczace spadku w rozporzadzeniu spadkowym Unii Europejskiej. Warszawa 2018.

Pazdan J., w: Prawo prywatne międzynarodowe. Komentarz. Red. J. Poczobut. Warszawa 2017.

Pazdan M.: O niektórych osobliwościach poszukiwania prawa wtaściwego. W: „Valeat aequitas”. Księga pamiatkowa ofiarowana Księdzu Profesorowi Remigiuszowi Sobańskiemu. Red. M. Pazdan. Katowice 2000.

Pazdan M.: O różnych funkcjach zdolności do czynności prawnych osoby fizycznej z uwzględnieniem aspektów arbitrażowych $i$ kolizyjnoprawnych. W: Prawo prywatne $i$ arbitraż. Księga jubileuszowa dedykowana doktorowi Maciejowi Tomaszewskiemu. Red. J. Poczobut, A.W. Wiśniewski. Warszawa 2016.

Pazdan M.: Prawo prywatne międzynarodowe. Warszawa 2012.

Pazdan M.: Rozszczepienie statutu kontraktowego oraz inne odstepstwa od zasady jednolitości statutu kontraktowego. „Studia Iuridica Silesiana” 1991, T. 126.

Pazdan M.: Stosowanie obcych norm kolizyjnych. „Problemy Prawa Prywatnego Międzynarodowego" 2016, T. 18.

Pazdan M.: Zarzad sukcesyjny - aspekty kolizyjnoprawne. W: Prawo handlowe. Między teoria, praktyka a orzecznictwem. Księga jubileuszowa dedykowana Profesorowi Januszowi A. Strzepce. Red. E. Zielińska, P. Pinior, P. Relidzyński, W. Wyrzykowski, M. Żaba. Warszawa 2019.

Pazdan M.: Zarzadca sukcesyjny a wykonawca testamentu. W: „Ius est ars boni et aequi”. Księga pamiatkowa dedykowana Profesorowi Józefowi Frąkowiakowi. Red. A. Dańko-Roesler, M. Leśniak, M. Skory, B. Sołtys. Wrocław 2018.

Pazdan M.: Zasada jednolitości statutu spadkowego $i$ odstępstwa od niej $w$ rozporzadzeniu spadkowym UE z 2012 r. W: Prawo prywatne wobec wyzwań wspótczesności. Księga pamiatkowa dedykowana Profesorowi Leszkowi Ogiegle. Red. M. Fras, P. Ślęzak. Warszawa 2017.

Pazdan M., w: Kodeks cywilny. T. 2: Komentarz. Art. 450-1088. Przepisy wprowadzajace. Red. K. Pietrzykowski. Warszawa 2018.

Pazdan M., w: Prawo prywatne międzynarodowe. Komentarz. Red. M. Pazdan. Warszawa 2018.

Pazdan M., w: Prawo spótek handlowych. T. 2A. Red. A. Szumański. Warszawa 2019.

Pazdan M., w: „System Prawa Prywatnego”. T. 20A: Prawo prywatne międzynarodowe. Red. M. Pazdan. Warszawa 2014.

Pilich M.: Zasada obywatelstwa w prawie prywatnym międzynarodowym. Zagadnienia podstawowe. Warszawa 2015.

Prawo prywatne międzynarodowe. Komentarz. Red. J. Poczobut. Warszawa 2017. 
Rodziewicz P.: Stwierdzenie treści oraz zastosowanie prawa obcego $w$ sqdowym postepowaniu cywilnym. Warszawa 2015.

Schmidt T.S.: The incidental question on private international law. „Recueil des Cours" 1992, II (T. 233).

Sieradzka M.: Zarzad sukcesyjny przedsiębiorstwem osoby fizycznej - analiza i ocena nowych rozwiazań prawnych. Cz. 1. „Monitor Prawniczy” 2018, nr 22.

Solomon D.: Die Anknüpfung von Vorfragen im Europäischen Internationalen Privatrecht. In: Fastschrift für Ulrich Spellenberg. Hrsg. J. Bernreuther, R. Freitag, S. Leible, H. Sippel, U. Wanitzek. Sellier 2010.

Sośniak M.: Prawo prywatne międzynarodowe. Katowice 1978.

Szereda A.: Przedsiębiorstwo w spadku - odrębna jednostka organizacyjna. W: Notarialne poświadczenie dziedziczenia. Red. A. Marciniak. Warszawa 2019.

Walaszek B., Sośniak M.: Zarys prawa międzynarodowego prywatnego. Warszawa 1973.

Waszczuk-Napiórkowska J.: Zapis windykacyjny w polskim prawie spadkowym. Warszawa 2014.

Wengler W.: Die Vorfrage im Kollisionsrecht, Zeitschrift für ausländisches und internationales Privatrecht. „Rabels Zeitschrift für ausländisches und internationales Privatrecht” 1934.

Wengler W.: Nouvelles réflexions sur les „questions préalables”. „Revue critique de droit international privé" 1966.

Zachariasiewicz M.A.: Przepisy wymuszajace swoje zastosowanie a statut spadkowy. W: Nowe europejskie prawo spadkowe. Red. M. Pazdan, J. Górecki. Warszawa 2015. 